\title{
Dilated fetal bowel as indication for prenatal diagnosis of cystic fibrosis
}

\author{
Raquel Soares, ${ }^{1}$ Paula Neto, ${ }^{2}$ Nuno Pereira, ${ }^{3}$ Catarina Cunha, ${ }^{4}$ Carla Pinto, ${ }^{5}$ Margarida Fonseca, ${ }^{2}$ \\ Lina Ramos, ${ }^{6}$ Eulália Galhano ${ }^{3}$
}

${ }^{1}$ Hospital Pediátrico de Coimbra, Centro Hospitalar de Coimbra, Coimbra, Portugal

${ }^{2}$ Maternidade Bissaya Barreto - Unidade de Cuidados Intensivos Neonatais, Centro Hospitalar de Coimbra, Coimbra, Portugal

${ }^{3}$ Maternidade Bissaya Barreto - Centro de Diagnóstico Pré-Natal, Centro Hospitalar de Coimbra, Coimbra, Portugal

${ }^{4}$ Hospital Pediátrico de Coimbra - Serviço de Cirurgia Pediátrica, Centro Hospitalar de Coimbra, Coimbra, Portugal

${ }^{5}$ Hospital Pediátrico de Coimbra - Unidade de Cuidados Intensivos, Centro Hospitalar de Coimbra, Coimbra, Portugal

${ }^{6}$ Serviço de Genética Médica, Centro Hospitalar de Coimbra, Coimbra, Portugal

Correspondence to Raquel Soares, araquelcs@yahoo.com

\section{Summary}

Dilated fetal bowel is a sonographic finding that is associated to meconium ileus, a feature of cystic fibrosis (CF). Prenatal diagnosis of CF is possible through analysis of the cystic fibrosis transmembrane regulator gene mutations.

A male infant is described, who was referred to our Prenatal Diagnosis Center a 17th week of gestation with a dilated bowel loop on a prenatal scan. Amniocentesis was performed at 23rd week gestation and a homozygous F508del mutation was found. He was born at 38 weeks gestation, after an otherwise unremarkable pregnancy, and admitted to Neonatal Intensive Care Unit. He showed progressive abdominal distension without stools and was transferred to another Hospital to surgery. A total occlusion of terminal ileum with meconium and a microcolon were found, and resection of $8 \mathrm{~cm}$ of ileum and an ileostomy were performed.

The characteristic sonographic finding of a dilated bowel is an indication to search for CF mutations.

\section{BACKGROUND}

Ultrasonographic (US) image of dilated fetal bowel can be a sign of intestinal obstruction: bowel atresia or stenosis, malrotation with volvulus, intestinal duplication, meconium ileus and meconium plug syndrome. The prevalence of cystic fibrosis (CF) in the presence of dilated intestinal loops is uncertain, with only one study ${ }^{1}$ presenting a prevalence of $33 \%$. Other prenatal US signs suggestive of CF are hiperechogenic bowel, echogenic masses or pseudocysts, ascites and intraperitoneal calcifications. Ruiz et af

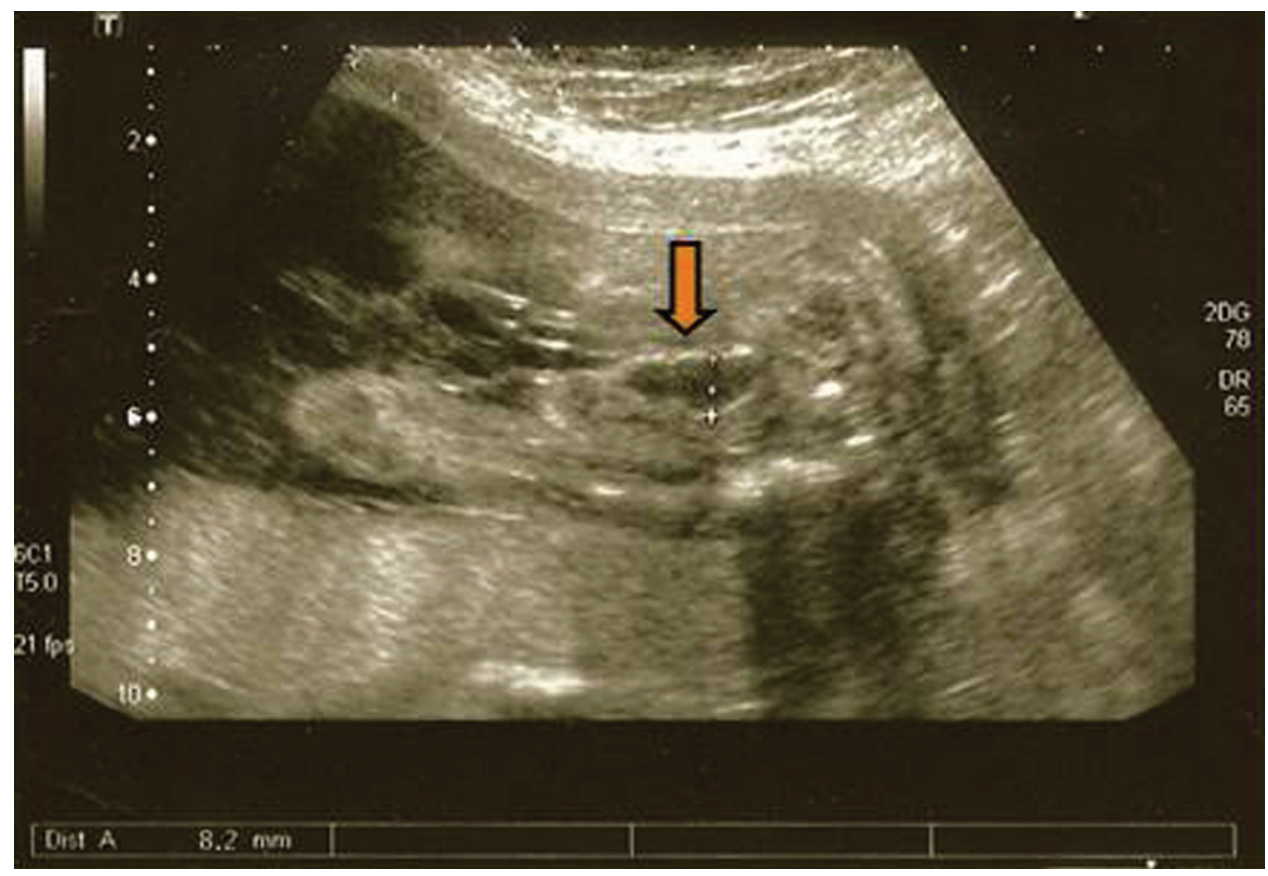

Figure 1 Ultrasound scan at 23rd week gestation, showing dilated loop of bowel (8.2 mm). 


\section{BMJ Case Reports}

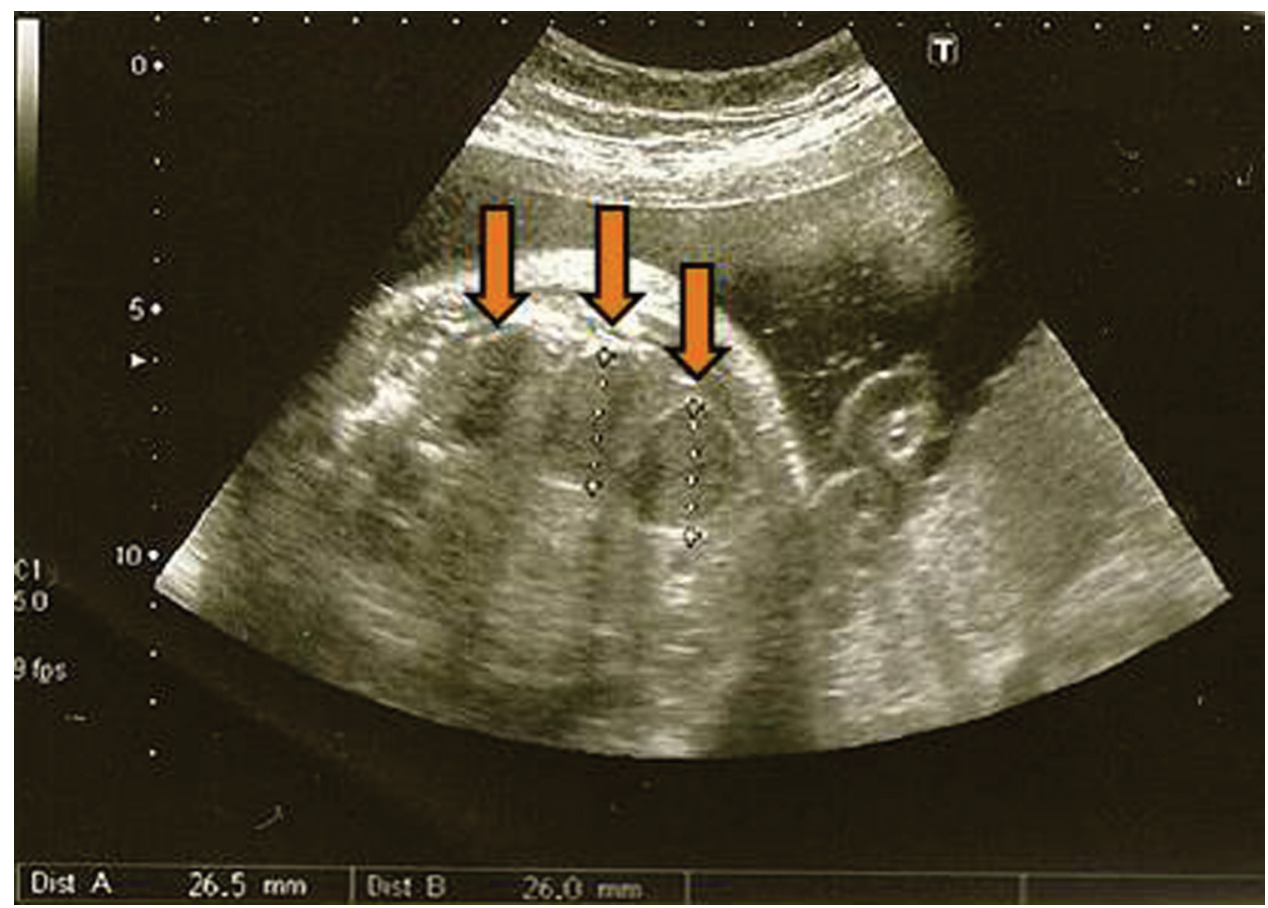

Figure 2 Ultrasound scan at 37th week gestation with multiple dilated bowel loops $(26 \mathrm{~mm})$ and polyhydramnios.

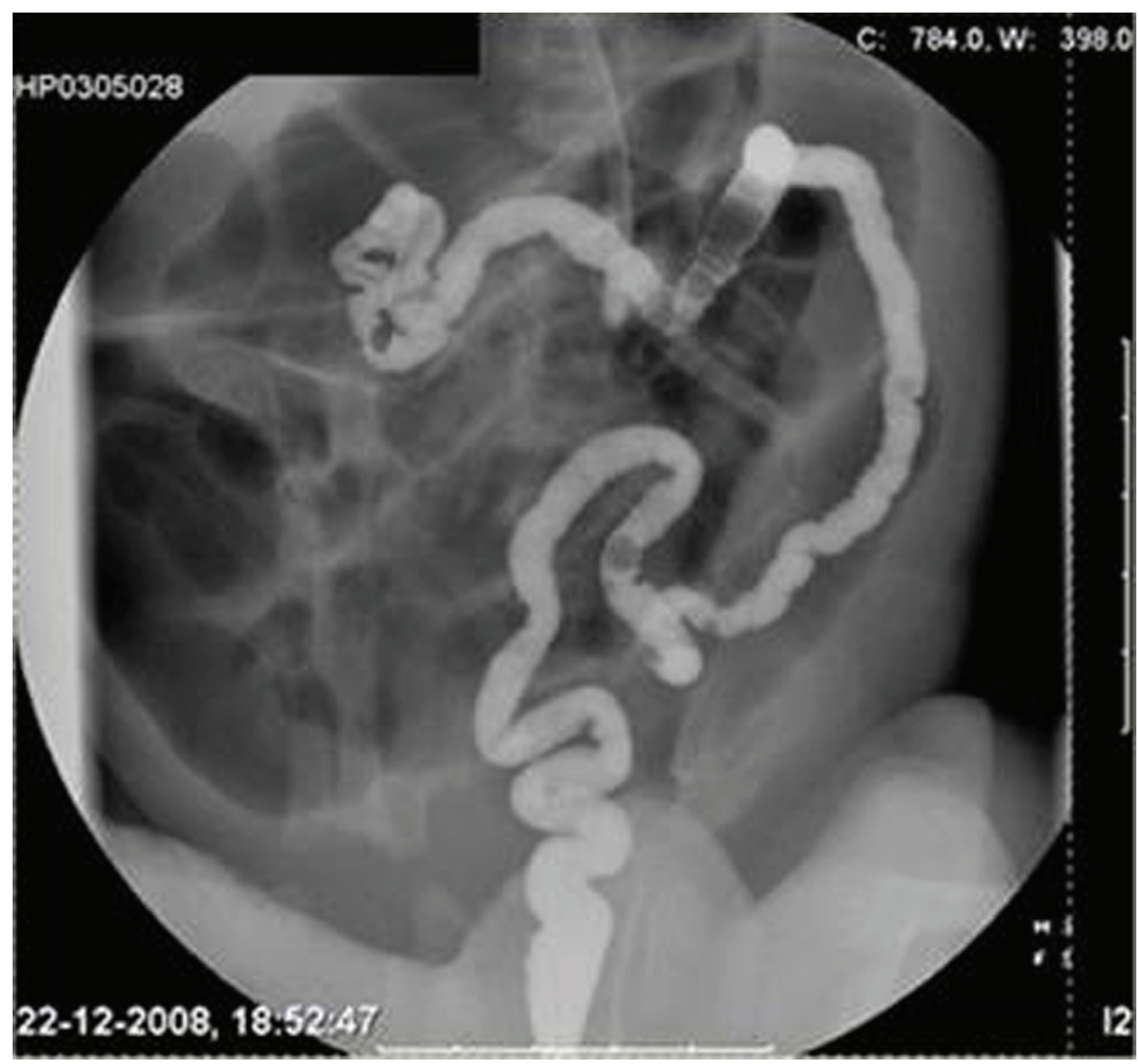

Figure 3 Gastrografin enema performed at 3rd day of life: microcolon and no contrast progression over hepatic flexure. 

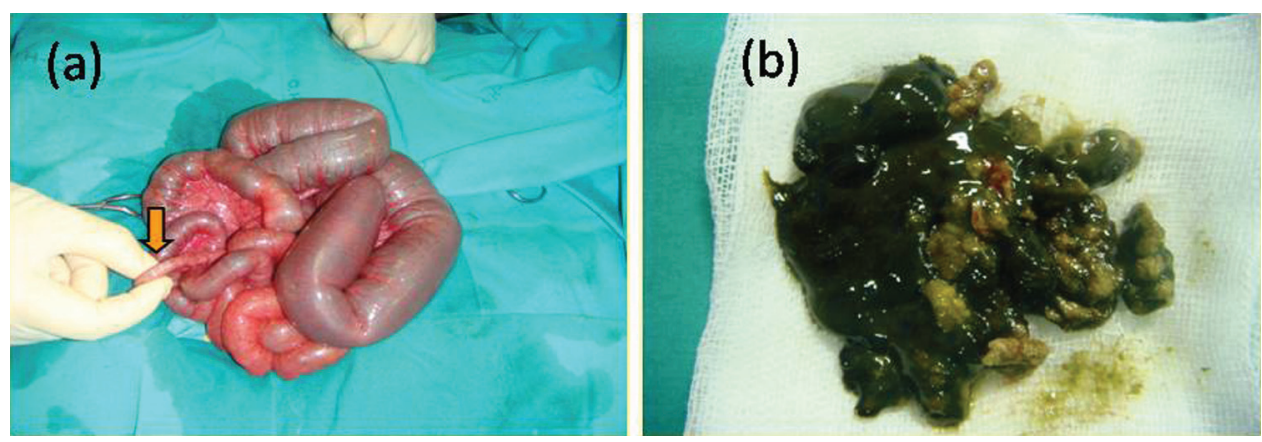

Figure 4 Surgery performed at 3rd day of life: (A) extremely dilated small-bowel loops, total occlusion of terminal ileum (arrow) with meconium; (B) viscid meconium found at terminal ileum.

evaluated neonatal outcome of abnormal intestinal appearance on fetal US and found that of 9 fetuses with persistent hyperechogenic bowel, $33.3 \%$ had meconium peritonitis or meconium ileus, and in 12 cases of prenatal dilated bowel, $66.7 \%$ born with an abnormality, most commonly intestinal atresia.

$\mathrm{CF}$, the most common autosomal recessive disease, manifests in the early neonatal period as meconium ileus in $15-20 \%$ of cases. ${ }^{3}$ The characteristic viscous and dehydrated secretions from exocrine glands that cause obstruction of bowel, airways and pancreatic ducts, results of mutations in the gene of cystic fibrosis transmembrane regulator (CFTR), responsible for altered epithelial cell electrolyte transport. The incidence of CF in Portugal is about 1/6000 live births and the prevalence of the most common mutation, $\Delta \mathrm{F} 508 \mathrm{del}$, is $2.2 \% .{ }^{4}$ There is relationship between genotype and phenotype, with the categorised 'severe' $\Delta \mathrm{F} 508$ del mutation being associated with worst pancreatic insufficiency and pulmonary function. Prenatal screening for CF by DNA mutation analysis is recommended in the presence of a family history of CF and in all pregnancies with US images of intestinal obstruction, like dilated or hyperechogenic bowel, the last defined as echogenicity comparable to bone.

\section{CASE PRESENTATION}

A male infant is described, who presented a dilated bowel in an ultrasound exam performed at 17 th week gestation.

The mother was referred to the Prenatal Diagnosis Center at Maternidade Bissaya Barreto where the fetal sonography at $23 \mathrm{rd}$ weeks confirmed a dilated loop (figure 1). Investigation procedures were taken, infections like cytomegalovirus and other were excluded and amniocentesis was performed. Fetal chromosome analysis revealed 46,XY and CF mutation analysis identified a $\triangle$ F508del in an homozygous form. After being informed of diagnosis and prognosis, the couple decided to proceed with the pregnancy. $\Delta$ F508del mutation, in heterozygous form, was found in both progenitors. There was no consanguinity and family history was unremarkable in what concerns to CF. The couple oldest son was an healthy 7-year boy. Monthly fetal scans revealed progressive severe bowel enlargement with multiple loops involved and polyhydramnios (figure 2). No other sonographic abnormalities where found.

A vaginal delivery, with vacuum extraction, was taken at 38 weeks gestation The newborn weight was $3660 \mathrm{~g}$ and Apgar scores were 9 and 10 at 1 and 5 min.

He showed abdominal distension, with poor gastric content, and a permeable rectum and was admitted to Neonatal Intensive Care Unit with a nasogastric tube. Worsening of abdominal distension was apparent in the first hours and he passed no stools even after stimulation.

At 12th hour of life he was transferred to a surgical neonatal unit for surgery evaluation. Acetyllcisteine and gastrografin enemas were ineffective (figure 3). Laparotomy was then performed and total occlusion of the lower part of the ileum with viscid meconium and microcolon were found (figure 4). Resection of $8 \mathrm{~cm}$ of ileum and an ileostomy was performed.

At 6 th day of life there was worsening of abdominal distention and a new gastrografin enema trough ileostomy was performed. Large quantities of meconium material were eliminated. He started oral feeding at 11th day with good tolerance and was delivered home at 18th day of life.

\section{DISCUSSION}

Rush et al ${ }^{5}$ reported a case of a fetal echogenic bowel and a dilated loop of bowel associated with CF mutations $\Delta$ F508 and 2183AA $\rightarrow$ G. On amniocentesis, only the $\Delta$ F508 mutation in heterozygous form was identified, but as the risk of CF was high, the couple elected to terminate the pregnancy.

Estroff et $a l^{1}$ reviewed US images and medical records of 15 fetuses with bowel dilated loops and found that 5 of them $(33 \%)$ had CF. There were no major US differences between fetuses with or without CF.

This case illustrates that when a dilated loop of bowel is found on fetal ultrasound, investigation for CF mutations on the fetal DNA must be undertaken, for counselling porpoises. Prenatal diagnosis is also essential to anticipate postnatal problems and provide optimal clinical management of the affected infant. The knowledge of the couple CFTR mutations will be important for future prenatal counselling. 


\section{BMJ Case Reports}

\section{Learning points}

- When a dilated loop of bowel is found on fetal ultrasound, CF must be considered.

- Prenatal screening for CF, by DNA mutation analysis, is possible.

- Prenatal diagnosis is essential for counselling porpoises and to provide optimal clinical management of the affected infant.

Competing interests None.

Patient consent Obtained.

\section{REFERENCES}

1. Estroff JA, Parad RB, Benacerraf BR. Prevalence of cystic fibrosis in fetuses with dilated bowel. Radiology 1992;183:677-80.

2. Ruiz MJ, Thatch KA, Fisher JC, et al. Neonatal outcomes associated with intestinal abnormalities diagnosed by fetal ultrasound. J Pediatr Surg 2009; 44:71-4; discussion 74-5.

3. Rennie JM, Roberton NRC. Textbook of neonatology. 3rd edn. Philadelphia: Pennsylvania, USA: Churchill Livingstone, 1999. Cystic Fibrosis p.758-759 Gastrointestinal disorders Part 3. Newel SJ. Ch.31 Gastroenterology.

4. Teixeira M. Frequência da mutação F508del no gene CFTR na população portuguesa. Tese de Mestrado em Genética Molecular. Universidade do Minho. Escola de Ciências, 2007.

5. Rush PW, Vats S, Allitto BA, et al. Fetal echogenic bowel and a dilated loop of bowel associated with cystic fibrosis (CF) mutations delta F508 and 2183AA-> G. Prenat Diagn 1998;18:638-40.

This pdf has been created automatically from the final edited text and images.

Copyright 2010 BMJ Publishing Group. All rights reserved. For permission to reuse any of this content visit http://group.bmj.com/group/rights-licensing/permissions.

BMJ Case Report Fellows may re-use this article for personal use and teaching without any further permission.

Please cite this article as follows (you will need to access the article online to obtain the date of publication).

Soares R, Neto P, Pereira N, Cunha C, Pinto C, Fonseca M, Ramos L, Galhano E. Dilated fetal bowel as indication for prenatal diagnosis of cystic fibrosis. BMJ Case Reports 2010;10.1136/bcr.03.2010.2868, date of publication

Become a Fellow of BMJ Case Reports today and you can:

- Submit as many cases as you like

- Enjoy fast sympathetic peer review and rapid publication of accepted articles

- Access all the published articles

- Re-use any of the published material for personal use and teaching without further permission

For information on Institutional Fellowships contact consortiasales@bmjgroup.com

Visit casereports.bmj.com for more articles like this and to become a Fellow 